\title{
VARIATION IN SPOTTING AMONG THE CLOSE RELATIVES OF THE BUTTERFLY, MANIOLA JURTINA
}

\author{
J. F. D. FRAZER \\ The Nature Conservancy, 19-20 Belgrave Square, London SW1 \\ and \\ H. N. A. WILLCOX \\ 10 Beech Walk, London NW7
}

Received 1.ii.74

\begin{abstract}
Summary
A study of spotting in seven related butterfly species in the genera Maniola and Pyronia has been initiated, in the hope of complementing previous work on Maniola jurtina. Marked individual variability has been found in six of the species. Stability of spotting over large areas has not been prominent, but a high degree of apparent geographical variability has been found in four species.

Sometimes this has taken the form of clines and sometimes of quantal steps. Some of the quantal changes coincide with the appearance of different "subspecies". Among the incomplete data presented, parallel geographical variation in different species has not been an obvious feature. There have not been enough samples to test for temporal variation in spotting.
\end{abstract}

\section{InTRODUCTION}

DOWDESWELL, FORD and collaborators have worked for many years on spotting in the Meadow Brown butterfly Maniola jurtina L. They showed firstly that, although there was great variability in spot numbers in each sex, the proportions of butterflies with the different numbers of spots (spot distributions) remained constant over most of the south of England, and over many seasons (Dowdeswell and Ford, 1952). They later found that almost identical distributions extended over the great bulk of the geographical range of the species in Europe (Dowdeswell and McWhirter, 1967).

At the edge of the range, however, a variety of different distributions occurred, as in some rather isolated colonies in the Scilly Isles (Dowdeswell and Ford, 1953; Dowdeswell et al., 1957; Creed et al., 1964), and in much larger areas in Iberia and North Africa (Dowdeswell and McWhirter, 1967). The females were consistently more variable than the males, one particularly dramatic example being the very abrupt change in their spotting found at the Devon/Cornwall border (Creed et al., 1959 and 1970).

Several instances of localised interseasonal variation were also found, sometimes correlated with obvious ecological changes (Dowdeswell et al., 1957); in other cases many areas in southern England varied in parallel (Creed et al., 1959). Finally, Frazer (in Greed et al., 1959) and later others (Creed et al , 1959; Beaufoy et al., 1970) found localities where female spotting decreased after the early weeks of a single season.

In all these studies, the number of different distributions was few, and Dowdeswell and McWhirter (1967) concluded that only a limited number of so-called stabilisations was available. They felt that powerful selective forces were acting on polygenes controlling spotting, both to generate the 
specialised populations at the edge of the range, and to maintain the widespread stabilisations thought to be more broadly adapted to the average environmental conditions of the middle of the range (see Ford, 1971).

The work reported here is an attempt to put the situation in $M$. jurtina into perspective by taking a comparative approach. Spotting occurs in

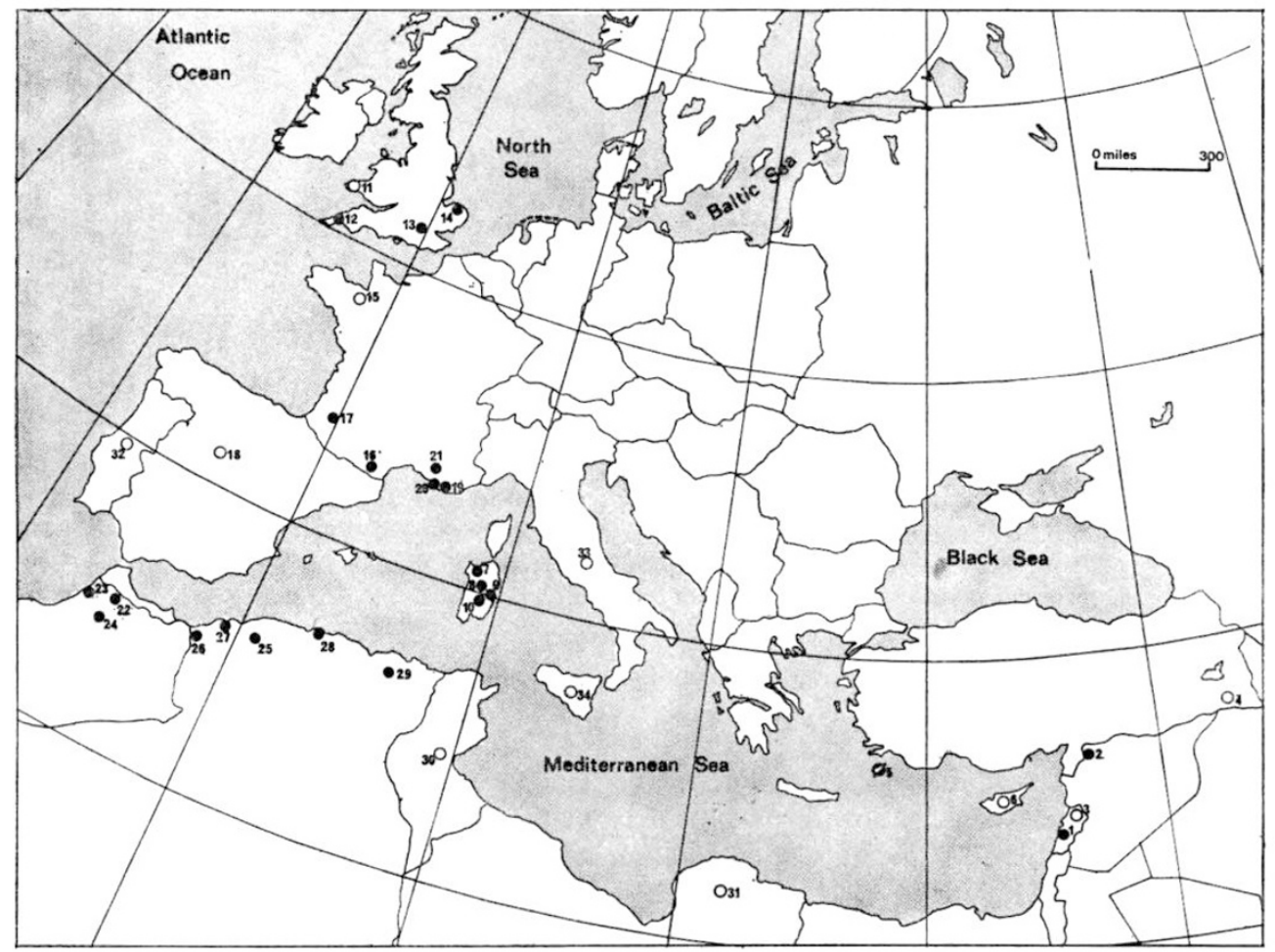

FIG. 1.-Sampling sites for all species other than $M$. jurtina are represented by dots. Circles relate to more generalised localities for miscellaneous collections. Keys to sites: 1. Beirut; 2. Akbes; 3. Lebanon; 4. Kurdistan; 5. Rhodes; 6. Cyprus; 7. Sassari; 8. Sorgono; 9. Gennargentiu; 10. Aritzo; 11. Pembrokeshire; 12. Cornwall; 13. Windsor; 14. Holme; 15. Ile et Vilaine; 16. Vernet-les-bains; 17. Pau; 18. San Ildefonso; 19. Marseille; 20. Carry-le-Rouet; 21. Mausanne; 22. Salé; 23. Rabat; 24. Middle Atlas; 25. Sebdou; 26. Masser Mines; 27. Oran; 28. Algiers; 29. Lambèse; 30. Tunisia ; 31. Cyrenaica; 32. Portugal; 33. Italy; 34. Sicily.

almost all the satyrids, and is variable in many of them. Rather than concentrate on a single species, we have studied closely related species in the genera Maniola and Pyronia, over as much of their geographical range and as many seasons as possible. We also hoped to extend the observation of parallel variation in separate species made by Dowdeswell and McWhirter (1967). The species chosen are listed in a classification modified after de Lesse (1952).

Maniola: jurtina, nurag, megala, telmessia.

Pyronia: tithonus, cecilia, bathseba, janiroides.

$M$. hispulla has been treated as a subspecies of $M$. jurtina and $M$. cypricola of $M$. telmessia. These species are probably all single-brooded, though some 
may have a very prolonged emergence period, and they are confined to Europe, North Africa, and Asia Minor. Though obviously limited by the climate and region in which they occur, they tend to occupy broadly similar habits.

\section{Methods}

Almost all of the specimens were scored by one of us only (H.N.A.W.), as the criteria of a spot are somewhat subjective. A hand lens was used throughout. Through the courtesy of the Trustees of the British Museum (Natural History) we have had the privilege of examining all of the specimens of the listed species available there. These include some large series, but also many specimens in twos and threes from different dates in different localities within a region. These have been added together in the results, and where a variety of different localities has been pooled, the result is called miscellaneous (misc.). Where there are many samples of different dates, but from apparently the same locality, the name of the locality and range of dates is given. In taking collections ourselves, we have been careful to avoid selecting for spotting; we cannot be sure that the Museum collections are similarly unbiased, though it seems likely.

Spots may occur on both surfaces of both wings in certain fixed positions, which coincide precisely on the two surfaces. On the forewings, there are two, behind the apical ocelli, known by us as $\alpha$ and $\beta$. On the hindwings there are six named $A-F$ on the upper surface and $a-f$ on the under, from before backwards. Most of the data refer to the total number of spots on a given surface of a given wing. In all the species except $M$. megala they are small and very variable in size. Under-surface spots and forewing spots are black, and may have a white pupil. In general, on the undersurface, the spots consist of a white pupil, with a black surround, and a white or yellow zone outside this. In different individuals or species different elements of this pattern may be lacking.

\section{Results}

(i) M. jurtina

A more complete account of spotting in this species is given by Dowdeswell and McWhirter (1967). Our results are included solely for comparison with the other species and because our scoring does not always agree with theirs (both scoring systems are internally consistent, and they can, to some extent be correlated). We have neglected those parts of the range where none of the other species occur, and the results are not analysed in detail.

\section{(a) Distribution}

M. jurtina ranges from the British Isles, W. Europe and Canary Islands eastwards as far as Sweden, European Russia, Greece, Turkey, Iran, southwards to Sicily, Malta, North Africa.

\section{(b) Spotting}

On the underside, $\alpha$ and $\beta$ may occur, and $a, b, d, e$, and $f$ are common, though $c$ is extremely rare. $A-F$ are almost unknown. 


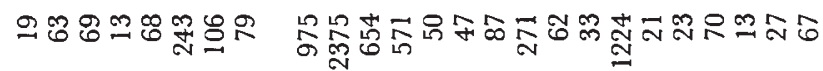

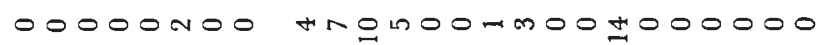

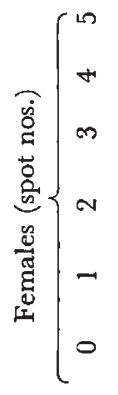

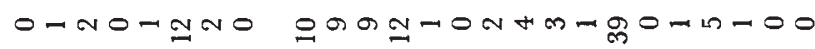

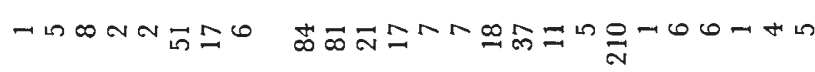

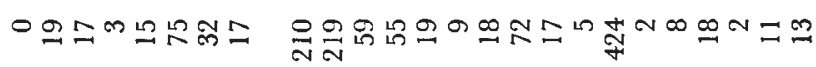

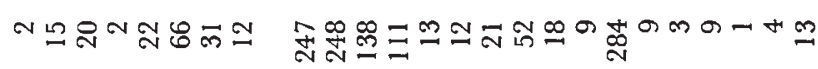

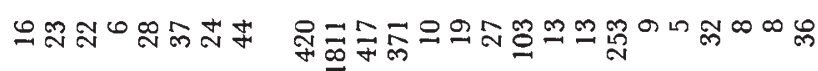

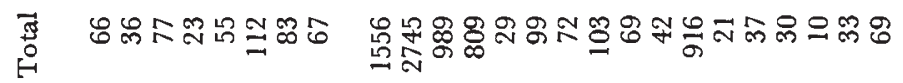

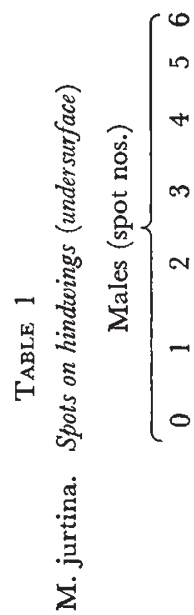
$0000000000-0000000000000-$

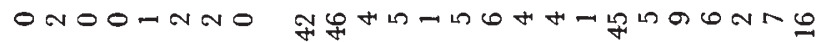

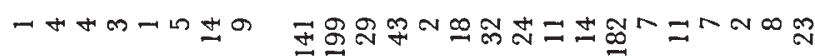

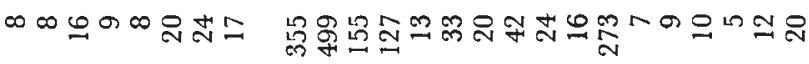

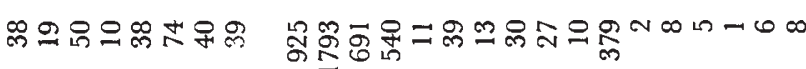

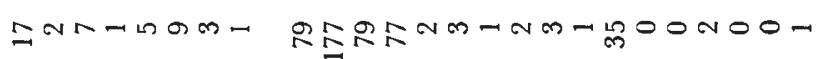
NTOONNOH

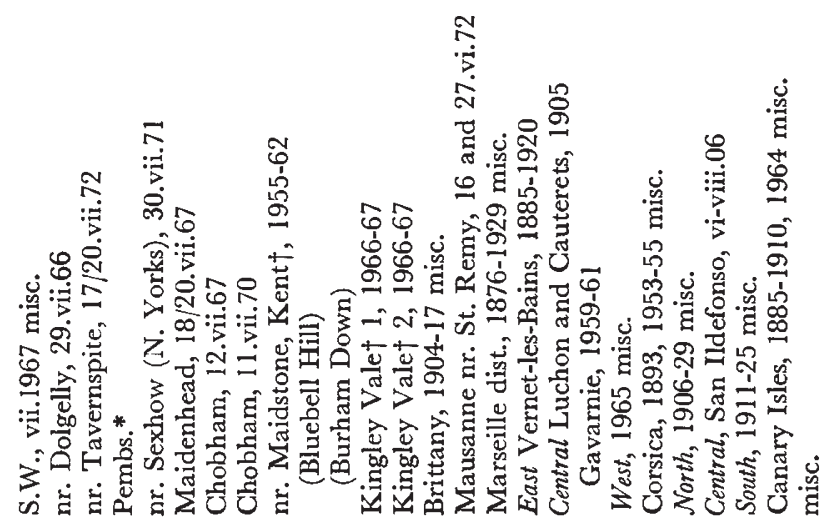

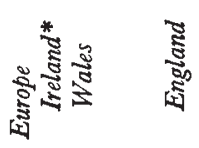

छั 


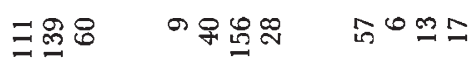

OAn OH- 0000

Hom ong- mooo

ヘே ๓

ลูำ

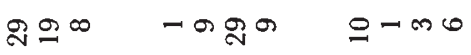

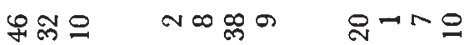

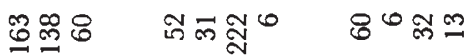

0000000 nooo

ㄴํำ ำชู० ำm

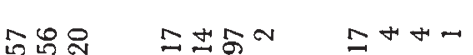

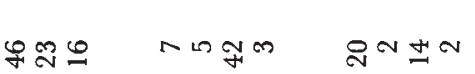

man nm⿻- $\quad$ no=0

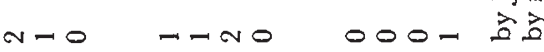

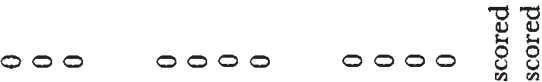

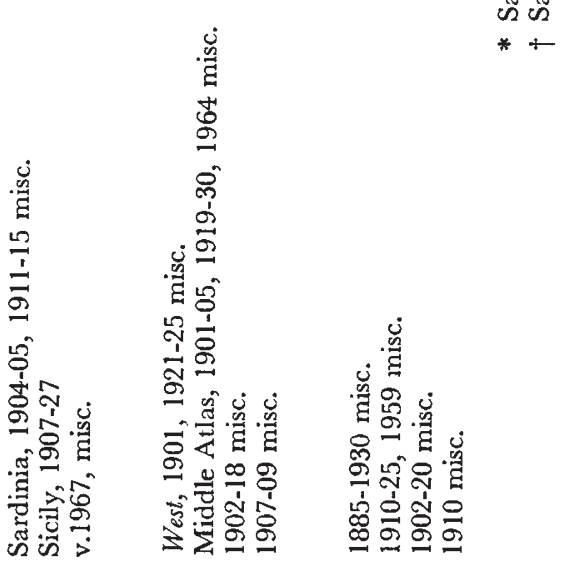

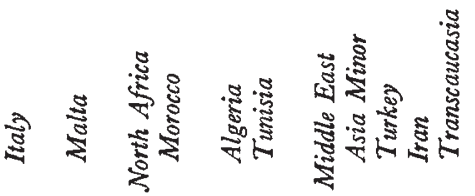


(c) Variation (see table 1)

Males: There is a clinal trend of low spotting in the north-west (esp. Ireland) which gives way to progressively higher spotting as one moves southwards through England, France, Spain, and into North Africa and Asia Minor. In the west and central Pyrenees, there is, apparently, a return towards the lower spotting characteristic of south-east England.

Females: Four main distributions occur. One is unimodal at 0 spots and occurs in Ireland and parts of southern England, one is unimodal at 2 and is found in parts of southern England, Brittany and the western and perhaps central Pyrenees. These are the "Old English" and "New English" distributions of Dowdeswell et al. A third is bimodal with the greater mode at 0 and the lesser at 2 spots, and is found at Vernet in the east Pyrenees, in the Marseille district, in central Spain and in Sardinia. It also seems to occur in Asia Minor. The final distribution is bimodal with the greater mode at 2 spots and the lesser at 0 and is found in Algeria, Scilly and Malta.

Male/female correlation: The correlation between the male and female spotting is poor, and all we can say is that, in general, where the male spotting is modal at 2 , the female spotting tends to be unimodal at 2 also. Where the male spotting is higher, the female spotting tends to be bimodal at 0 and 2. However, in Ireland the spotting of both sexes is very low, and there are several other exceptions to the above rule.

\section{(ii) M. megala}

\section{(a) Distribution}

M. megala occurs in Syria; and possibly elsewhere in the Middle East. (We have only seen six males and nine females of the species from various parts of Syria, 1890-91.)

\section{(b) Spotting}

On the underside of the hindwings, spots $a, b, d, e$ and $f$ are common, and on the forewings, $\alpha$ and $\beta$ occur. On the upperside, spot $E$ was seen in one male only.

\section{(c) Variation}

One male had 3 spots on the underside of the hindwing and the rest 5 . One female had 1 spot, two had 2 spots, three had 3 spots, three had 4 spots and one had 5 .

\section{(iii) M. telmessia}

\section{(a) Distribution}

M. telmessia occurs around the Eastern Mediterranean, extending inland into Asia Minor, Syria, Iran, and perhaps Greece, and occurs in island forms on Cyprus (cypricola), Rhodes (ornata), Lesbos and Karpathos.

\section{(b) Spotting}

Spots $a, b, d, e$ and $f$ occur in all areas, but $c$ only in Rhodes. Spot $E$ is the only upper surface spot and is mainly found on Rhodes. Spots $\alpha$ and $\beta$ occur rarely. 
(c) Variation (see table 2)

The female samples are even fewer and smaller than the males but, though consistently lower spotted, they nevertheless seem to vary in parallel with them. The Syrian samples are low-spotted and homogeneous in each sex, and a small collection from Kurdistan is similar. The Rhodes collections are remarkably higher spotted, with some males even having 6 spots.

TABle 2

M. telmessia. Spots on hindwings (undersurface)

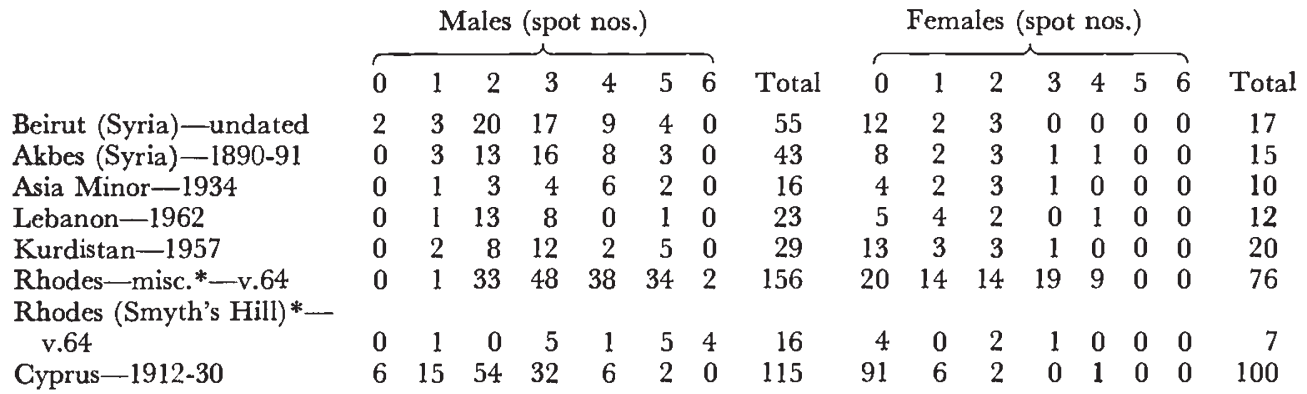

* These samples were scored by J.F.D.F., but the one from Smyth's Hill was confirmed by H.N.A.W. For $\chi^{2}$ and $\mathrm{P}$ values, see text.

The difference is highly significant in each sex $\left(\chi^{2}=18 \cdot 2, \mathrm{P}<0.001\right.$ in the males, $\chi^{2}=12.6, \mathrm{P}<0.001$ on the females). The Cyprus series is even lower spotted than the Syrian, and this difference is highly significant $\left(\chi^{2}=17.66, \mathrm{P}<0.001\right)$ in the males. Less than a tenth of the Cypriot females have any spots at all, but the Syrian sample is too small for statistical comparison.

\section{(a) Distribution}

(iv) $M$. nurag

M. nurag is confined to Sardinia, where it is said to fly only in cork and olive groves, along with $M$. jurtina (Greenwood and Greenwood, 1966).

(b) Spotting

Spots $a, b, d, e$ and $f$ may be found and, very rarely, the upper-surface spot $E$ may occur. Spots $\alpha$ and $\beta$ occur rarely.

(c) Variation (see table 3)

The samples are small, but there is a suggestion that spotting in Sassari is different from elsewhere.

TABLE 3

M. nurag. Spots on hindwings (undersurface)

\begin{tabular}{|c|c|c|c|c|c|c|c|c|c|c|c|c|c|}
\hline \multicolumn{6}{|c|}{ Males (spot nos.) } & & \multicolumn{6}{|c|}{ Females (spot nos.) } & \multirow[b]{2}{*}{ Total } \\
\hline 0 & 1 & 2 & 3 & 4 & 5 & Total & 0 & 1 & 2 & 3 & 4 & 5 & \\
\hline 1 & 2 & 11 & 4 & 7 & 2 & 27 & 5 & 1 & 4 & 0 & 2 & 0 & 12 \\
\hline 1 & $\overline{2}$ & 12 & 9 & 4 & 2 & 30 & 3 & 2 & 0 & 0 & 0 & 0 & 5 \\
\hline 0 & 1 & 3 & 6 & 6 & 5 & 21 & 5 & 11 & 8 & 2 & 0 & 0 & 26 \\
\hline
\end{tabular}

Aritzo-1904-20

Gennargentiu-1902-14

Sassari-1896 
(v) P. tithonus

\section{(a) Distribution}

$P$. tithonus occurs in north, central and southern Europe, as far as Spain, Sardinia, North Italy, Greece and Asia Minor. It lacks the north-eastern distribution of M. jurtina.

\section{(b) Spotting}

Spots occur on both surfaces of both wings, being in positions $B, C, D$ and $E$ and $a, b, c, d, e$ and $f$ on the hindwings.

(c) Variation (see tables 4 and 5)

Statistical analysis of the findings is given in Frazer and Willcox (1974).

TABLE 4

P. tithonus. Spots on hindwings (upper surface)

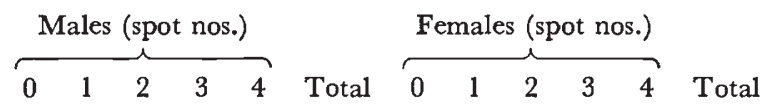

Wales

Pembrokeshire coastline

(Nolton Haven to Strumble Head), 29.vii-6.viii.65

England

Phillack, 25.vii.66

Gunwalloe, 24.vii.66

Thame, 30.vii.66

Windsor, 30.vii.67

Holme to Naze (E. Anglia), vii.69

France

Ile et Vilaine (Brittany), 1917

Vernet-les-Bains (E. Pyrenees), 18861908 misc.

Vernet-les-Bains, 1909

Vernet-les-Bains, 1920

Pau (W. Pyrenees), viii.65

Spain

San Ildefonso (nr. Madrid), vi-viii.06

$\begin{array}{rrrrrrrrrrrr}3 & 36 & 23 & 23 & 30 & 115 & 0 & 9 & 18 & 1 & 2 & 30 \\ 6 & 30 & 11 & 4 & 1 & 52 & 0 & 10 & 9 & 0 & 0 & 19 \\ 11 & 32 & 8 & 8 & 3 & 62 & 1 & 9 & 9 & 0 & 1 & 20 \\ 4 & 49 & 15 & 8 & 6 & 82 & 0 & 19 & 30 & 0 & 0 & 49 \\ 13 & 60 & 13 & 5 & 2 & 93 & 1 & 25 & 30 & 0 & 1 & 57 \\ 2 & 38 & 11 & 4 & 2 & 57 & 0 & 2 & 1 & 0 & 0 & 3 \\ 10 & 21 & 6 & 1 & 0 & 38 & 1 & 10 & 15 & 0 & 0 & 26 \\ 14 & 21 & 4 & 1 & 0 & 40 & 5 & 26 & 5 & 0 & 0 & 36 \\ 12 & 29 & 11 & 3 & 0 & 55 & 3 & 32 & 7 & 0 & 0 & 42 \\ 31 & 49 & 4 & 1 & 0 & 85 & 5 & 39 & 9 & 0 & 0 & 53 \\ 9 & 20 & 4 & 0 & 0 & 33 & 7 & 21 & 6 & 0 & 0 & 34 \\ 53 & 47 & 0 & 0 & 0 & 100 & 21 & 29 & 1 & 0 & 0 & 51 \\ 1 & 24 & 9 & 5 & 1 & 40 & 0 & 6 & 2 & 0 & 0 & 8\end{array}$

Italy

Sorgono (Sardinia), 1911

The results in this and subsequent tables have been analysed in detail statistically. Tables of $\chi^{2}$ and $\mathbf{P}$ values have been deposited in Evolutionary Genetics Research Reports (See Frazer and Willcox, 1974).

Only significant differences are discussed in the text, and most are highly significant.

Male upper surface. The Pembrokeshire series is very highly spotted, almost half of the butterflies having 3 or 4 spots. The five English samples are much lower spotted, and the Brittany and Vernet samples somewhat lower still. There is a suggestion of interseasonal change at Vernet, the 1909 series being significantly higher than the other two, resembling the battered sample from Pau. The central Spanish sample (from San Ildefonso) is much lower spotted even than the one from Vernet in 1920, while the Sardinian distribution is very similar to the English.

In short, spotting is high in Pembrokeshire, and there is a trend towards lower spotting as we go southwards through France and into Spain.

Female upper surface. Unlike the males, the Pembrokeshire females are 


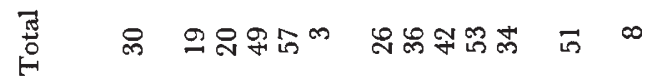

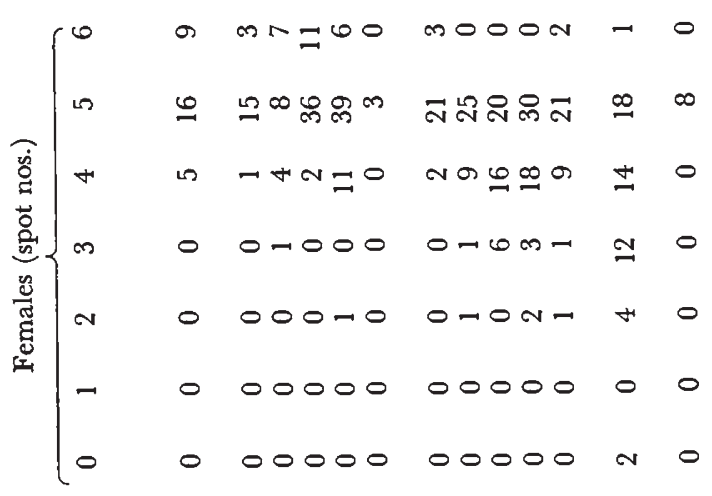

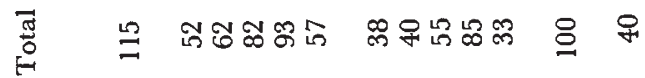

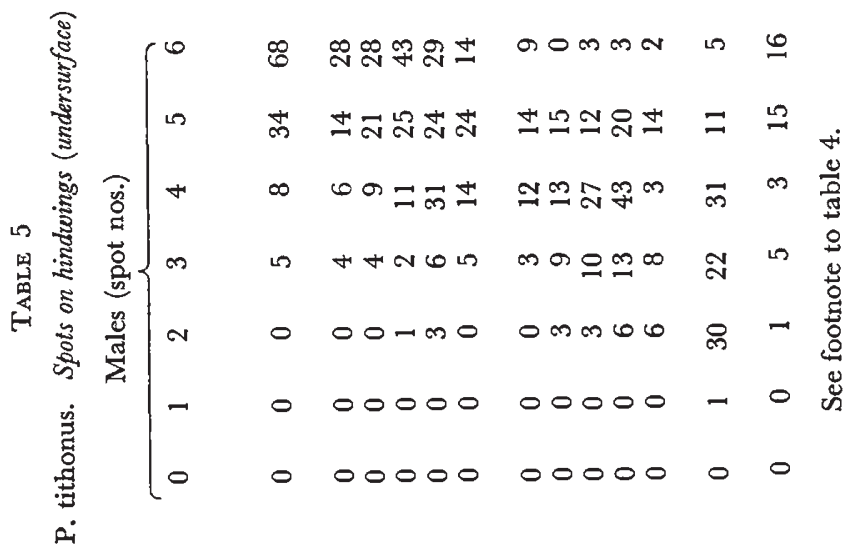

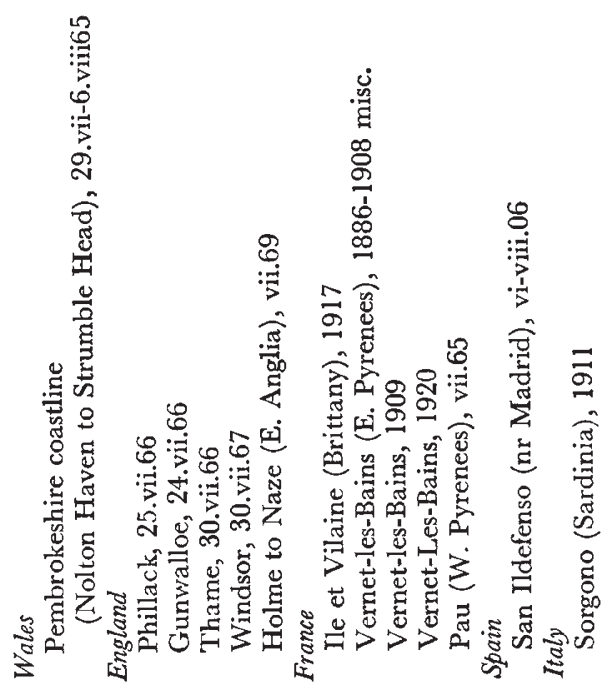


homogeneous with the Southern English, and are modal at 2 spots. The Brittany sample is similar, but the Vernet samples are somewhat lower spotted, though still modal at 2, and are highly significantly different from the British. They show no evidence of a change in distribution over the year, and the Pau sample is homogeneous with them. Again, the spotting in San Ildefonso is much lower. The Sardinian sample is too small for comparison.

Under-surface spot weight. The spots in descending order of frequency are $E, D, C, B$.

Male undersurface. The spotting is high in southern England and Wales (modal at 6 spots), one sample from Windsor and one from East Anglia, however, giving a significantly lower distribution. This is similar to that found in Brittany, but the samples from Vernet are considerably lower spotted (modal at 4), and differ very significantly from the British. The San Ildefonso spotting is much lower still, with modes at 2 and 4 spots, and this difference is again highly significant. The Sardinian distribution is similar to the Southern English.

Female undersurface. Excepting the slightly lower spotted Windsor series, the British and Brittany samples are homogeneous, and the Vernet samples, themselves also homogeneous, are significantly lower spotted. The Pau series is identical and that from San Ildefonso is again lower still.

Undersurface spot weight. Spots $b$ and $e$ are almost universal, and $a$ and $f$ are the next commonest. The greater frequency of the spots $d, c$ and $a$ in the British samples is largely responsible for their difference from the Spanish one.

Surface correlation. In all localities, spotting in individuals is strongly, but not absolutely correlated on the two surfaces (see also summary).

Forewing spotting occurs in about a tenth of the specimens in all localities except Sardinia, where it occurs in nearly half. It is slightly commoner on the upper surface, but is not common enough to be correlated with hindwing spotting.

Summary. The same trend, of high spotting in Britain and Sardinia, intermediate in Vernet and low in San Ildefonso, is obvious in both sexes and on both surfaces, though the changes are less dramatic in the females.

(vi) P. cecilia

\section{(a) Distribution}

$P$. cecilia occurs around the Western Mediterranean, in Spain, Portugal, southern France, Italy, Sardinia, Sicily, Yugoslavia, Greece, Asia Minor and in North Africa from Morocco to Cyrenaica. Its emergence is somewhat earlier in North Africa and Sicily (April-July) and in Europe (May or June-August).

\section{(b) Spotting}

Spots $a, b, d$ and $e$ occur commonly. Spot $c$ is rare, and $f$ unknown, and spots on the upper surface of the hindwing are almost unknown. Extra spots $\alpha$ and $\beta$ occur rarely.

Spots $a-e$, when they do occur, may be black and easily discernible, or may be brown or white and very hard to distinguish from their mottled background. These types of spot have been scored separately, and the scores 
of the black spots are probably much more reliable. However, in Cyrenaica, where the background pigmentation is darker and more uniform than elsewhere, the white spots can be seen to be genuine.

\section{(c) Variation}

Males. Black spots are rarely found in Europe, though they do occur in about a fifth of the French and about a third of the Italian males and are very common in Sicily (in about three-quarters of the specimens). In North Africa they are much more frequent than in Europe. Black spotting

TABLE 6

\section{P. cecilia}

Total spot nos.

Black spot nos.

\section{Europe}

France

Marseille dist., 1886-7, 1918-23

Vernet-les-Bains, 1909, 1920-21

$\begin{array}{lrrrrrrrrrr}\mathrm{M} & 15 & 17 & 13 & 14 & 1 & 60 & 48 & 6 & 4 & 2 \\ \mathrm{~F} & 17 & 10 & 5 & 0 & 0 & 32 & 31 & 1 & 0 & 0 \\ \mathrm{M} & 12 & 9 & 1 & 0 & 0 & 22 & 16 & 6 & 0 & 0 \\ \mathrm{~F} & 35 & 6 & 0 & 0 & 0 & 41 & 36 & 5 & 0 & 0\end{array}$

Spain

North, 1896-1929

South, 1879-1910

Portugal, 1880-1940

Italy

Mainland, 1887-1925

Sardinia, 1898-1911

Sicily, 1901-27

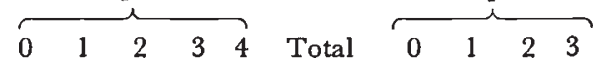

\section{North Africa}

\section{Morocco}

West, 1901-1927

East-Zoudj el Beghal, 1914

Algeria

North-west-Oran Misc., 1914

North, Central-Algiers dist., 1905-10

North-east, 1884-86

Lambèse, 1884-85, 1912-13

Tunisia, 1909-15

\section{Libya \\ Cyrenaica, 1922, 1953-54}

$\begin{array}{lrrrrrrrrrr}\text { M } & 18 & 9 & 5 & 2 & 1 & 35 & 33 & 2 & 0 & 0 \\ \mathrm{~F} & 14 & 2 & 0 & 0 & 0 & 16 & 16 & 0 & 0 & 0 \\ \mathrm{M} & 13 & 12 & 15 & 5 & 0 & 45 & 40 & 3 & 2 & 0 \\ \mathrm{~F} & 6 & 1 & 1 & 1 & 0 & 9 & 8 & 1 & 0 & 0 \\ \mathrm{M} & 10 & 13 & 2 & 0 & 0 & 25 & 23 & 2 & 0 & 0 \\ \mathrm{~F} & 19 & 8 & 1 & 0 & 0 & 28 & 27 & 1 & 0 & 0\end{array}$

$\begin{array}{lrrrrrrrrrr}\mathrm{M} & 10 & 18 & 11 & 4 & 0 & 43 & 28 & 13 & 2 & 0 \\ \mathrm{~F} & 6 & 8 & 3 & 2 & 0 & 19 & 13 & 6 & 0 & 0 \\ \mathrm{M} & 10 & 5 & 3 & 0 & 0 & 18 & 16 & 2 & 0 & 0 \\ \mathrm{~F} & 6 & 2 & 1 & 0 & 0 & 9 & 9 & 0 & 0 & 0 \\ \mathrm{M} & 10 & 36 & 29 & 10 & 0 & 85 & 21 & 42 & 22 & 0 \\ \mathrm{~F} & 12 & 17 & 2 & 0 & 0 & 31 & 14 & 17 & 0 & 0\end{array}$

$\begin{array}{lrrrrlrrrrr}\text { M } & 15 & 21 & 19 & 13 & 2 & 70 & 48 & 15 & 6 & 1 \\ \text { F } & 7 & 12 & 7 & 0 & 0 & 26 & 16 & 10 & 0 & 0 \\ \text { M } & 17 & 37 & 33 & 9 & 0 & 96 & 41 & 39 & 16 & 0 \\ & & & & & & & & & & \\ \text { M } & 1 & 17 & 24 & 13 & 0 & 55 & 17 & 29 & 8 & 1 \\ \text { F } & 2 & 4 & 0 & 0 & 0 & 6 & 4 & 2 & 0 & 0 \\ \text { M } & 2 & 4 & 3 & 7 & 1 & 17 & 9 & 6 & 2 & 0 \\ \text { F } & 8 & 21 & 7 & 2 & 0 & 38 & 17 & 21 & 0 & 0 \\ \text { M } & 23 & 36 & 30 & 16 & 0 & 105 & 65 & 34 & 6 & 0 \\ \text { F } & 12 & 5 & 4 & 0 & 0 & 21 & 15 & 6 & 0 & 0 \\ \text { M } & 11 & 11 & 13 & 7 & 1 & 43 & 22 & 16 & 5 & 0 \\ \text { F } & 18 & 6 & 0 & 0 & 0 & 24 & 21 & 3 & 0 & 0 \\ \text { M } & 5 & 9 & 11 & 17 & 1 & 43 & 25 & 12 & 6 & 0 \\ \text { F } & 21 & 19 & 3 & 0 & 0 & 43 & 39 & 4 & 0 & 0 \\ & & & & & & & & & & \\ \text { M } & 4 & 18 & 17 & 2 & 2 & 43 & 42 & 1 & 0 & 0 \\ \text { F } & 8 & 10 & 19 & 0 & 0 & 37 & 37 & 0 & 0 & 0\end{array}$

Abbreviations $\quad \mathrm{M}=$ Male $\mathrm{F}=$ Female

All except the Vernet, Zoudj-el-Beghal and Lambese samples are from a mixture of sites and even these are from several dates.

Because of uncertainty as to the validity of these data (see also text section on spotting) they have not been analysed in detail statistically. 
is moderately high in West Morocco, higher in a good series from East Morocco, and higher still in West Algeria, before falling off in East Algeria and Tunisia. There are almost no black spots in Cyrenaica, but in Sicily their distribution is very similar to that in West Algeria, and is the highest of all.

White spotting is moderately high in the Marseille region, and in Spain and Italy, but is at its very lowest in Vernet. It is uniformly high in North Africa, especially further east in Tunisia and Cyrenaica. Although, in general, the European samples show less of either type of spot than the North African, detailed analysis of the results shows no correlation between the incidence of black and white spots.

TABLE 7

P. bathseba. Spots on hindwings (upper surface)

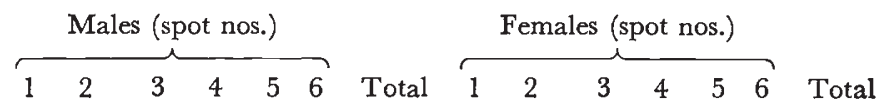

Europe

France

Marseille dist. misc., 1901-25

Carry-le-Rouet, 1-2.vi.72

Maussane, 14.vi.72

Vernet-les-Bains, 1886-1914

Spain

1906-09 and 1924-29, misc.

$\begin{array}{rrrrrrrrrrrrrr}0 & 3 & 26 & 53 & 0 & 0 & 82 & 0 & 1 & 23 & 23 & 0 & 0 & 47 \\ 0 & 0 & 24 & 89 & 1 & 0 & 114 & 0 & 0 & 12 & 44 & 1 & 0 & 57 \\ 0 & 7 & 35 & 17 & 0 & 0 & 59 & 0 & 1 & 21 & 23 & 0 & 0 & 45 \\ 0 & 1 & 28 & 19 & 0 & 0 & 48 & 0 & 1 & 11 & 6 & 0 & 0 & 18 \\ 0 & 9 & 77 & 20 & 4 & 0 & 110 & 0 & 1 & 45 & 21 & 4 & 1 & 72\end{array}$

\section{North Africa}

Morocco

West: Salé and Rabat, 1925

elsewhere, 1924-29

Middle Atlas, 1934

Algeria

Sebdou, v.07 and 1918

Masser Mines (nr. Oran), v-vil4

Oran, 1913-18

Misc. other sites, 1910-20

$\begin{array}{rrrrrrrrrrrrrr}1 & 44 & 15 & 1 & 0 & 0 & 61 & 1 & 22 & 15 & 1 & 0 & 0 & 39 \\ 2 & 13 & 20 & 1 & 0 & 0 & 36 & 0 & 3 & 0 & 0 & 0 & 0 & 3 \\ 0 & 3 & 25 & 1 & 0 & 0 & 29 & 0 & 4 & 8 & 1 & 0 & 0 & 13 \\ & & & & & & & & & & & & & \\ 0 & 2 & 48 & 17 & 2 & 0 & 69 & 0 & 1 & 12 & 1 & 0 & 0 & 14 \\ & & & & & & & & & & & & & \\ 0 & 12 & 207 & 92 & 20 & 2 & 333 & 0 & 3 & 104 & 34 & 13 & 0 & 154 \\ 0 & 3 & 37 & 22 & 2 & 0 & 64 & 0 & 0 & 17 & 9 & 0 & 0 & 26 \\ 0 & 0 & 23 & 3 & 2 & 0 & 28 & 0 & 1 & 15 & 5 & 1 & 0 & 22\end{array}$

See footnote to table 4 .

Females. The female spotting (of both types), while it is correlated with the male spotting, is almost universally lower. With the Spanish, Portuguese, West Moroccan and Algerian samples, the black spotting is much closer to that of the males than is the white. The samples are small.

(vii) P. bathseba

(a) Distribution

$P$. bathseba occurs in a more limited area around the Western Mediterranean than $P$. cecilia, viz. S. France, Spain, Portugal, and in North Africa from Morocco to Algeria.

\section{(b) Spotting}

Spots occur in all positions known-i.e. spots $A-F$ and $a-f$ on the hindwings (though spot $c$ is unusual), and $A$ and $B$ on both surfaces of the forewings. 
(c) Variation (see tables 7 and 8)

The male/female correlation is so perfect that the two sexes will be considered together. Statistical analysis of the findings is given in Frazer and Willcox (1974).

Hindwings. The geographical variation is dramatic and clear, with a peak in upper-surface spotting in the Marseille region, declining gently (but significantly) through Vernet into Spain. Very much lower spotting is found in West Morocco, but the mixed specimens from other parts of Morocco show slightly higher spotting, and the small Middle Atlas sample is

TABLE 8

P. bathseba. Spots on forewing (upper surface)

$\overbrace{012}^{\begin{array}{c}\text { Males } \\ \text { (spot nos.) }\end{array} \text { Total } \overbrace{0}^{1} 2} \begin{gathered}\text { Females } \\ \text { (spot nos.) }\end{gathered}$ Total

Europe

France

Marseille dist. misc., 1901-25

Carry-le-Rouet, 1-2.vi.72

Maussane, 14.vi.72

Vernet-les-Bains, 1886-1914

Spain

1906-09 and 1924-29, misc.

$\begin{array}{rrrrrrrr}16 & 49 & 1 & 66 & 6 & 28 & 0 & 34 \\ 63 & 51 & 0 & 114 & 22 & 35 & 0 & 57 \\ 44 & 15 & 0 & 59 & 20 & 25 & 0 & 45 \\ 30 & 17 & 0 & 47 & 14 & 2 & 0 & 16 \\ 60 & 18 & 0 & 78 & 27 & 28 & 0 & 55\end{array}$

North Africa

Morocco

West: Salé and Rabat, 1925

elsewhere, 1924-29

Middle Atlas, 1934

Algeria

Sebdou, v.07 and 1918

Masser Mines (nr. Oran), v-vi.14

Oran, 1913-18

Misc. other sites, 1910-20

$\begin{array}{rrlrrrrr}6 & 52 & 3 & 61 & 10 & 27 & 2 & 39 \\ 29 & 4 & 0 & 33 & 3 & 0 & 0 & 3 \\ 22 & 2 & 0 & 24 & 7 & 3 & 0 & 10 \\ 49 & 19 & 1 & 69 & 9 & 5 & 0 & 14 \\ 225 & 107 & 1 & 333 & 89 & 62 & 3 & 154 \\ 42 & 21 & 0 & 63 & 13 & 11 & 1 & 25 \\ 23 & 5 & 0 & 28 & 13 & 9 & 1 & 23\end{array}$

See footrote to table 4 .

Only the main samples from each locality have been included in this table-hence the slightly smaller totals than in table 6 .

higher again. It is unequivocally intermediate between the West Moroccan and Algerian samples, which are homogeneous and show higher spotting still, not unlike the Spanish. On the underside, in nearly every locality at least 90 per cent of the butterflies have 5 spots, a very few having 4 or 6 . The exception is in West Morocco, where almost a third have 4 spots or fewer.

The close resemblance in spotting between the 1901-25 Marseille series, and the single 1972 collection from nearby Carry-le-Ruet is remarkable. (The Carry-le-Rouet spotting is even higher on the hindwings, but somewhat lower on the forewings. See tables 7 and 8). It suggests that this spotting may have been stable over a long time, and that such very mixed samples as the earlier one may be meaningful. The difference between the Maussane and Carry-le-Rouet collections (separated by a mere 40 miles in space, and 2 weeks in time) is also highly significant and suggests that the Marseille region spotting pattern may be very localised. It would be extremely interesting to define more carefully the areas in which these distributions occur, 
especially in view of the boundary phenomena in $M$. jurtina (Creed et al., 1959 and 1970). Thorough checking of the only suitable samples-those from Masser Mines-has revealed no evidence of intraseasonal variation in either sex, but the Maussane-Carry difference could conceivably be temporal even so.

Spot weight. Spots $D$ and $E$ are almost universal, and $B$ is also very common (except in West Morocco). In Europe, spot $\mathrm{C}$ is also fairly common and $A$ almost unknown, whereas in Algeria $A$ is slightly commoner than $C$. On the undersurface, spot $c$ is rare, and in West Morocco, spot $f$ may be missing as well.

The correlation between upper and undersurface spotting is only detectable in West Morocco, as it is only here that both are variable. and here the correlation is strong.

Forewings. The forewing spot $\alpha$ is very much commoner in $P$. bathseba than in any of the other species studied, occurring in more than 20 per cent of the butterflies in most localities. It follows the upper hindwing spotting very precisely, with one striking exception. This is that the West Moroccan series with the very low hindwing spotting, has even higher forewing spotting than the Marseille samples. The undersurface spotting is consistently less than the upper, and on both surfaces $\beta$ is rare, only occurring together with $\alpha$.

Correlation of fore and hindwing spotting. There is a slight tendency for individuals with extra spots $\alpha$ and $\beta$ on their forewings to have higher hindwing spotting than the rest of the sample. It is particularly true of the French and West Moroccan samples, and is not found in the Algerian. As we have stated, geographical variation is closely correlated on the fore and hindwings.

(a) Distribution

(viii) $P$. janiroides

$P$. janiroides is confined to Algeria and Tunisia, and we have few samples.

(b) Spotting

Spots occur on the undersurface of the hindwing in positions $a-f$. Spots $\alpha$ and $\beta$ occur rarely.

(c) Variation (see table 9)

Spotting seems slightly higher in the females than the males, and in the females there is a suggestion that the spotting in Tunisia is different from that in Algeria.

\section{(ix) Generalisations}

Every species studied has shown great individual variability in nearly all localities studied, and often in several aspects of spotting. In general, the spotting on the forewing is much less variable than on the hindwing, and the spotting on the upper side of the hindwing less widespread than on the underside, though $P$. bathseba is exceptional.

In individuals, the correlation in spotting between the two surfaces of the hindwings is strong, when it can be tested. When we compare different populations, spotting on the two surfaces tends to vary in parallel in $P$. 
tithonus, but by no means always; in the one situation in $P$. bathseba where both vary, they also vary together. The correlation in spotting between the fore and hindwings is much less obvious in individuals, though perhaps significant. When we compare different populations of $P$. bathseba, fore and hindwing spotting are very precisely correlated, with the one exception of West Morocco.

In $M$. jurtina the spotting is often quite different in the two sexes, though their geographical variation may sometimes be correlated. The same is true for the other Maniola species, but in Pyronia, by contrast, the spotting is very similar in the two sexes. Interestingly, in $P$. tithonus and $P$. bathseba, geographical variation in the females is less extreme than that in the males, though they are closely correlated.

Algeria misc., 1898-1919

E. Algeria misc., 1907-09

Tunisia misc., 1910-11

TABle 9

P. janiroides. Spots on undersurface of hindwings.

\begin{tabular}{|c|c|c|c|c|c|c|c|c|c|c|c|c|c|c|c|}
\hline \multicolumn{7}{|c|}{ Males (spot nos.) } & \multicolumn{9}{|c|}{ Females (spot nos.) } \\
\hline 0 & 1 & 2 & 3 & 4 & 5 & 6 & Total & 0 & 1 & 2 & 3 & 4 & 5 & 6 & Total \\
\hline 2 & 6 & 6 & 6 & 9 & 5 & 0 & 34 & 0 & 0 & 6 & 1 & 11 & 8 & 0 & 26 \\
\hline 0 & 0 & 3 & 4 & 10 & 6 & 0 & 23 & 0 & 0 & 7 & 8 & 16 & 6 & 1 & 38 \\
\hline 2 & 0 & 3 & 12 & 16 & 2 & 0 & 35 & 1 & 1 & 12 & 12 & 18 & 4 & 0 & 48 \\
\hline
\end{tabular}

\section{Discussion}

(i) Geographical constancy and variation

One of the most remarkable findings of Dowdeswell, Ford and collaborators was that over all the variety of different habitats from southern England (since 1950), through west, central and north Europe, as far as southern France, Bulgaria and Finland (1890-1935), the only spotting variation encountered took the form of rather modest "second-order" differences. The distribution in this area they called the General European stabilisation, and their other important finding was that it tended to change at the periphery in various regions, allegedly by quantal shifts (McWhirter, 1957; Dowdeswell and McWhirter, 1967). The new spot distributions in these regions were also called stabilisations, though they were often confined to much smaller areas, and were not always stable from season to season (as in the Scilly Isles). The concept of stabilisations is obviously something of an over-simplification, since second-order differences exist within them, and intermediate distributions may be found which are hard to assign.

Our own results in $M$. jurtina may be suggestive of a western European stabilisation, but are certainly rather more heterogenous, although they cover a more restricted range, than those of Dowdeswell and McWhirter. Male spotting did not change in quantal steps from one region to another, but rather gradually in clines. Thus, as they concede, many different distributions intermediate between one modal at 2 spots and one with a flat-topped mode of 4 and 5 spots were encountered. However, in the females, which have always provided their best examples of contrasted stabilisations, it is true that a more limited number of distributions occurred, although again intermediates may be hard to classify and their occurrence is erratic. Hence, even in $M$. jurtina, the concept of stabilisations is of limited application.

With $M$. megala, $M$. nurag and $P$. janiroides, we cannot discuss geographical variation or stability because of the paucity of samples. Nor do we have 
enough series from the centre of the range of $M$. telmessia (on the Middle Eastern mainland), $P$. tithonus (in north and central Europe) nor even of $P$. bathseba (in Spain and Algeria) to define widespread stabilisations. In $P$. cecilia, the variation is erratic and inconsistent, and likewise shows no sign of stabilisation. Our most important findings, therefore, have been not of stabilisation, but of geographical variation, and this has taken two formsclines and quantal steps.

Clines. In $M$. jurtina males, there is a cline from low spotting in England to progressively higher distributions in Spain and particularly in North Africa, Sicily and Malta, but interrupted in the Pyrenees. The appearance of the high spotting may be related to that of a different subspecies in the south-hispulla - though the criteria of a subspecies are somewhat arbitrary.* In $P$. tithonus also, there is evidence of a cline from an extreme of high spotting in the British Isles (in the 1960's) to an extreme of low spotting in Spain (in the 1900's). Similarly in $P$. bathseba the Marseille distribution marks the summit of a cline which sinks gradually through the Pyrenees into Spain and reaches a very low level in West Morocco. Thence there is a second cline which rises again through the Middle Atlas and into Algeria, where there may even be a widespread stabilisation.

The existence of regular clines suggests that changing climatic factors may be playing some part in the control of spotting, perhaps by favouring selection of different genotypes. We cannot even discount the possibility that the different spotting patterns we have found are entirely the results of different environmental factors interacting with precisely the same genotype throughout. Indeed, there are many Indian species of Satyrids (e.g. in the genera Mycalesis, Yphthima, Melanitis), in which this seems to be exactly what happens. Grossly different spotting in wet and dry season forms is regularly found. However, the abrupt changes in spotting that occur over short distances in $M$. jurtina, and perhaps in some of the other species, are very hard to explain in this way.

Quantal Steps. The West Moroccan P. bathseba, because of its discordant forewing spotting which is quite distinct from that in its neighbours in Spain and Algeria, and because of its generally dark appearance (contrasting sharply with the brilliant Marseille region specimens) is clearly far removed from the rest of its cline, and this change represents a large quantal shift. Similarly, $P$. cecilia in Cyrenaica is much smaller and darker than from elsewhere, and its spotting is likewise unique. Both these forms might be held to represent separate subspecies.

In $P$. tithonus, though there is no gross difference in overall appearance in the Pembrokeshire sample, there is again a quantal shift in spot distribution from neighbouring samples, and the same may also be true in Sardinia. Likewise, in $M$. telmessia, there are extremes in spotting in two island populations, that in Rhodes being very high, and that in Cyprus being even lower than on the mainland. Both populations have been given subspecific status ( $M$. telmessia ornata in Rhodes and $M$. cypricola in Cyprus).

\section{(ii) Evolutionary significance of spotting}

The occurrence of divergent distributions at the edge of the range (perhaps representing new stabilisations) is strongly reminiscent of the

* In no other instance, however, have differences in spotting in $M$. jurtina been correlated with changes from one subspecies to another. 
situation in $M$.jurtina, and is likewise pronounced in islands at the periphery. It can be interpreted as evidence that a restricted group of genes has been selected as an adaptation to a specialised local environment, as argued by Ford (1971), although random factors cannot be discounted (Waddington, 1957). Where it coincides with subspeciation, the appearance of new distributions suggests that the genes may have been selected because of their contribution (by genetic interactions or linkage) to a co-adapted gene pool (Kettlewell, 1965), rather than because of the spotting per se. If the preliminary evidence (McWhirter, 1969) of its multifactorial inheritance can be confirmed, then spotting will acquire significance as a method of studying the evolution of polygenic characters. This is a process which has been inadequately studied as yet, but which may nevertheless contribute just as much to the adaptation of a species as its more conspicuous and more easily studied major genes.

\section{(iii) Possible correlations between species in spotting}

It is clearly of great interest to know whether species which overlap geographically vary in parallel in their spotting, as such evidence might help to identify common selective factors, local idiosyncrasies in the environment and so on. Unfortunately, so far, we have inadequate samples to test this in most cases, and only two correlations have emerged. In general, white spotting in $P$. cecilia is correlated with spotting in male $M$. jurtina, being low in most of southern Europe, but with a moderate peak in the Marseille region and rising higher in Sicily and North Africa. There are minor irregularities and the females are hard to compare, as there are seldom large samples of both species in the same area. Secondly, there is a fairly pronounced negative correlation between the spotting of $P$. tithonus and of male $M$. jurtina. Their clines from England to Spain (which we have already noted) are in opposite directions. The female $M$. jurtina shows a slight tendency to vary in the same direction as $P$. tithonus, with somewhat higher spotting in England, and lower in Vernet and Spain. In spite of several overlapping samples, neither $M$. jurtina nor $P$. cecilia are correlated with $P$. bathseba. The correlations between $P$. tithonus, $P$. cecilia and $P$. bathseba and between $M$. jurtina and $M$. telmessia are as yet very uncertain.

As different surfaces of different wings, and indeed males and females in the same species do not always vary together, it may be naive to expect different species to be correlated. However, commenting on the widespread occurrence of spotting in Satyrids and on the limited evidence of similar spotting in two samples each of $M$. jurtina and $M$. telmessia in Syria, the Lebanon and Cyprus, Dowdeswell and McWhirter (1967) write " The genes controlling spotting appear in other words to be trans-specific, trans-generic, trans-familial and, therefore, of great antiquity". These genes they dignify with the name " palaeogenes". It is disappointing that we do not yet have adequate data to confirm or refute this concept, either in this specific case, or in general. It is worth pointing out, however, that better documented palaeogenes exist, such as the structural genes for cytochrome $c$ (Dayhoff, 1972) and for the histone IV, in which there are only two amino-acid residue differences (out of 102) between the cow and the pea (De Lange and Smith, 1971). Compared with these, the spotting genes must be relatively recent. 
Acknowledgments.-We are grateful to Prof. R. J. Berry, Prof. W. H. Dowdeswell and Dr R. Holliday for reading the manuscript and for their helpful comments. We would like to thank the Trustees of the British Museum (Natural History) for enabling us to study their collections; and Messrs T. G. Howarth and M. P. Clifton for their great help in locating them. We are indebted to Dr L. G. Higgins, F.R.C.S., for kindly allowing us to study his collection, and are also extremely grateful to many collectors, notably A. Valletta, H. S. Barlow, Drs A. M. Hoare, C. P. W. and P. H. A. Willcox, and to our families for indulgence.

\section{REFERENGES}

BEAUFOY, E. M., BEAUFOY, s., DOWDESWELl, W. H., AND MCWHIRTER, K. G. 1970. Evolutionary studies on Maniola jurtina (Lepidoptera Satyridae). The southern English stabilisation, 1961-68. Heredity, 25, 105-112.

CREED, E. R., DOWDESWELL, W. H., FORD, E. B., AND MCWHIRTER, K. G. 1959. Evolutionary studies on Maniola jurtina; the English mainland, 1956-57. Heredity, 13, 363-391.

CREED, E. R., DOWDESWELl, W. H., FORD, E. B., AND MCWHIRTER, K. G. 1970 . Evolutionary studies on Maniola jurtina; the "Boundary Phenomenon" in Southern England, 1961 to 1968. Essays in Evolution and Genetics in Honour of Theodosius Dobzhansky (ed. M. K. Hecht and W. C. Steere). Appleton-Century-Crofts, New York (Meredith Corporation).

CREED, E. R., FORD, E. B., AND MCWHIRTER, K. G. 1964. Evolutionary studies on Maniola jurtina; the Isles of Scilly, 1958-59. Heredity, 19, 471-488.

DAYHOFF, M. о. 1972. Atlas of Protein Sequence and Structure, vol. 5. National Biochemical Research Foundation, Washington D.C.

DE LANGe, R. J., AND SMITH, E. L. 1971. Histones-structure and function. Ann. Rev.Biochem., 40, 279-314.

DE LESSE, H. 1952. Revision des anciens genres Pararge (S.L.) et Maniola = Epinephele (auct.). Ann. Soc. Ent. France, 121, 61-76.

DOWDESWELL, W. H., AND FORD, E. B. 1952. The distribution of spot number as an index of geographical variation in the butterfly Maniola jurtina, L. Heredity, 6, 99-109.

DOWDESWELL, W. H., AND FORD, E. B. 1953. The influence of isolation on variability in the butterfly Maniola jurtina L. Symposia Soc. Exp. Biol., 7, 254-273.

DOWDESWELL, W. H., FORD, E. B., AND MCWHIRTER, K. G. 1957. Further studies on isolation in the butterfly Maniola jurtina $\mathrm{L}$. Heredity, 11, 51-65.

DOWDESWELL, W. H., AND MCWHIRTER, K. G. 1967. Stability of spot distribution in Maniola jurtina throughout its range. Heredity, 22, 187-210.

FORD, E. B. 1971. Ecological Genetics, 3rd ed. Methuen, London.

FRAZER, J. F. D., AND WILlCOX, H. N. A. 1974. Spot numbers on the wings of butterflies in the genera Maniola and Pyronia in Europe and North Africa. Evolutionary Genetics Research Reports, 19 (16 pages). Filed at British Library Lending Division, Wetherby, W. Yorkshire and John Crerar Library, Chicago, U.S.A.

GREENWOOD, J. A. C., AND GREENWOOD, D. 1966. Some butterflies and moths in Sardinia, July and August, 1965. Ent. Rec., 78, 224-226.

KETTLEWELl, H. B. D. 1965. Insect survival and selection for pattern. Science, 1948, 1290-1296.

MCWHIRTER, K. G. 1957. A further analysis of variability in Maniola jurtina L. Heredity, 11, 351-371.

MCWHIRTER, K. G. 1969. Heritability of spot-number in Scillonian strains of the Meadow Brown Butterfly (Maniola jurtina L). Heredity, 24, 314-318.

waddington, с. H. 1957. The Strategy of the Genes. Allen and Unwin, London. 